\title{
6: 41588608-41845892
}

National Cancer Institute

\section{Source}

National Cancer Institute. 6: 41588608-41845892. NCI Thesaurus. Code C42340.

Physical location of FRS3_Gene 